\title{
PERAN BMT DARUSSALAM DALAM MEMENUHI KEBUTUHAN MAHASISWA UNIVERSITAS ISLAM RIAU
}

\section{THE ROLE OF BMT DARUSSALAM IN MEETING THE NEEDS OF RIAU ISLAMIC UNIVERSITY STUDENTS}

\author{
Putri Nuraini \\ Universitas Islam Riau \\ putrinuraini@fis.uir.ac.id
}

\begin{abstract}
The presence of BMT Darussalam is basically an idea to help ease the burden on students who need funds. The purpose of this study was to determine and analyze the role of BMT Darussalam in meeting the needs of students of the Faculty of Islamic Religion, Riau Islamic University. This research is a field research. The population in this study were students in the Faculty of Islamic Religion of Riau Islamic University who submitted funding for 2016 to 2018 totaling 88 people. The entire population was sampled using total sampling techniques. The data collection method is by observing, interviewing and distributing questionnaires. Data analysis is descriptive, data is grouped and described according to its type and analyzed using qualitative analysis, then presented in tabular form and supplemented with an explanation. The results of this study indicate that the existence of BMT Darussalam plays an active role in meeting the needs of students who need education funds in the form of financing programs, with a percentage of $87.69 \%$. From the program BMT became a mediator between students who needed funding and the University. Furthermore, all the needs of students both in the form of academic funding needs, the need for financing academic facilities and financing needs for entrepreneurship can be met properly by BMT Darussalam by $88.18 \%$.
\end{abstract}

Keywords: Role, BMT Darussalam, Student Needs, UIR

\begin{abstract}
ABSTRAK
Kehadiran BMT Darussalam pada dasarnya merupakan sebuah gagasan untuk membantu meringankan beban mahasiswa yang membutuhkan dana. Tujuan penelitian ini untuk mengetahui dan menganalisis peranan BMT Darussalam dalam memenuhi kebutuhan mahasiswa Fakultas Agama Islam Universitas Islam Riau. Penelitian ini merupakan penelitian lapangan (field research). Populasi dalam penelitian ini adalah mahasiswa di lingkungan Fakultas Agama Islam Universitas Islam Riau yang mengajukan pembiayaan tahun 2016 s/d 2018 sebanyak 88 orang. Seluruh populasi dijadikan sampel dengan menggunakan teknik total sampling. Adapun metode pengumpulan data dengan melakukan observasi, wawancara dan penyebaran kuesioner. Analisa data bersifat deskriptif, data dikelompokkan dan diuraikan sesuai dengan jenisnya dan dianalisis dengan menggunakan analisis kualitatif, kemudian disajikan dalam bentuk tabel serta dilengkapi dengan penjelasan. Hasil penelitian ini menunjukkan bahwa keberadaan BMT Darussalam berperan aktif dalam memenuhi kebutuhan mahasiswa yang membutuhakan dana pendidikan dalam bentuk program pembiayaan, dengan persentase sebesar $87.69 \%$. Dari program tersebut BMT menjadi
\end{abstract}


mediator antara mahasiswa yang membutuhkan dana dengan pihak Universitas. Selanjutnya, segala kebutuhan mahasiswa baik berupa kebutuhan pembiayaan akademik, kebutuhan pembiayaan sarana akademik dan kebutuhan pembiayaan untuk berwirausaha dapat terpenuhi dengan baik oleh BMT Darussalam sebesar $88.18 \%$.

Kata Kunci : Peranan, BMT Darussalam, Kebutuhan Mahasiswa, UIR

\section{PENDAHULUAN}

BMT adalah salah satu jenis lembaga keuangan bukan bank yang bergerak dalam skala mikro sebagaimana Koperasi Simpan Pinjam (KSP). Adapun bank umum merupakan lembaga keuangan makro sedangkan bank perkreditas rakyat merupakan lembaga keuangan menengah. Dari sekian banyak lembaga keuangan mikro seperti Koperasi, Bank Perkreditan Rakyat (BPR) dan lainnya, BMT merupakan lembaga keuangan mikro yang berbasis syariah. Baitul Maal Wat Tamwil merupakan salah satu lembaga keuangan syari'ah non perbankan, yang biasa disebut BMT (Haryoso, 2017).

\section{Baitul (BMT) Darussalam}

Fakultas Agama Islam (FAI) UIR adalah BMT yang berada dilingkungan Fakultas Agama Islam Universitas Islam Riau. BMT ini mempunyai beberapa produk diantaranya produk tabungan, pembiayaan, menerima dan menyalurkan zakat, produk pengelolaan dan penyaluran serta produk layanan dan jasa. Produk tabungan merupakan produk Simpanan Pendidikan Mahasiswa yang bersifat wajib dan dapat ditarik apabila mahasiswa yang bersangkutan dinyatakan lulus. Didirikannya BMT Darussalam ini bertujuan untuk membantu kebutuhan mahasiswa. Keberadaannya diharapkan mempunyai beberapa peranan penting antara lain membantu kebutuahankebutuahn mahasiswa dalam hal biaya pendidikan, mahasiswa yang memiliki jiwa kewirausahaan. Peranan merupakan suatu yang diharapkan dimiliki oleh orang yang memiliki kedudukan dalam masyarakat. Sedangkan peranan yaitu bagian dari tugas utama yang harus dilakukan.

Mahasiswa Fakultas Agama Islam Universitas Islam Riau merupakan orang-orang yang melakukan aktivitas pembelajaran didalam lingkup Universitas Islam Riau. BMT Darussalam senantiasa menyediakan bantuan untuk mahasiswa yang membutuhkan bantuan dana pendidikan. Pendirian BMT Darussalam ini merupakan salah satu upaya untuk membantu kebutuhan-kebutuhan mahasiswa dalam hal financial. Adapun bentuk bantuan dana yang diberikan kepada mahasiswa untuk memenuhi kebutuhannya adalah memberikan dana talangan kepada mahasiswa seperti: pertama, program pembiayaan akademik berupa biaya pendidikan (SPP, SKS dan KKN), keperluan skripsi, pembuatan VISA dan pembuatan KITAS. Kedua, program pembiayaan sarana akaemik berupa laptop, printer, handphone dan lain-lain. Ketiga, program pembiayaan untuk mahasiswa yang berwirausaha.

Jumlah pembiayaan dari program-program tersebut mengalami peningkatan dari tahun ke tahun. Pada tahun 2016 mahasiswa yang mengajukan pembiayaan sebanyak 10 orang, taun 2017 sebanyak 43 orang dan tahun 2018 sebanyak 35 orang. Adanya peningkatan jumlah mahasiswa yang mengajukan pembiayaan menandakan bahwa mahasiswa Fakultas Agama Islam UIR masih terkendala dalam hal financial untuk memenuhi kebutuhankebutuhannya. 
Penelitian ini oleh lebih terfokus pada BMT darussalam saja yang membahas mengenai Peranan BMT Darussalam dalam memenuhi Kebutuhan Mahasiswa Fakultas Agama Islam Universitas Islam Riau. Untuk itu penelitian ini mengadopsi sistem pengelolaan BMT yang telah lebih dulu dikaji oleh penelitian-penelitian terdahulu di antaranya Ismanto (2015), dan Pritandhari (2015) yang menemukan bahwa sistem pengelolaan BMT bagi mendapatkan manfaat untuk pelanggan (dalam hal ini mahasiswa) adalah melalui perbaikan kualitas pengelolaan dan pelayanan yang diberikan.

\section{METODE PENELITIAN}

Penelitian ini merupakan penelitian lapangan (field research). Jenis penelitian yang digunakan dalam penelitian ini adalah jenis penelitian deskriptif. Jenis penelitian deskriptif adalah jenis penelitian yang disusun dalam rangka memberikan gambaran secara sistematis tentang informasi ilmiah yang berasal dari subjek atau objek penelitian.

Penelitian ini dilaksanakan di

BMT (Baitul Maal wa Tamwil) Darussalam Fakultas Agama Islam Universitas Islam Riau (UIR) Pekanbaru yang beralamat di jalan Kaharuddin Nasution, Perhentian Marpoyan, Simpang Tiga, Pekanbaru Riau. Adapun objek penelitiannya adalaha Mahasiswa Fakultas Agama Islam Universitas Islam Riau yang mengajukan pembiayaan.

Populasi dalam penelitian ini adalah mahasiswa di lingkungan Fakultas Agama Islam Universitas Islam Riau tahun 2016 s/d 2018 yang mengajukan pembiayaan sebanyak 88 orang. Sampel adalah bagian dari jumlah dan karakteristik yang dimiliki oleh populasi tersebut, atau dengan kata lain sampel adalah bagian dari populasi (sebagian atau wakil dari populasi).
Seluruh populasi akan dijadikan sampel dengan menggunakan teknik total sampling.

Dalam mengumpulkan data untuk penelitian ini, digunakan beberapa metode yaitu sebagai berikut:

\section{Angket}

Angket adalah berupa daftar pertanyaan yang harus tercakup oleh pewawancara selama wawancara berlangsung. Tujuan angket adalah untuk mendapatkan informasi mengenai bagaimana peranan BMT Darussalam dalam memenuhi kebutuhan mahasiswa Fakultas Agama Islam UIR.

\section{Observasi}

Observasi, merupakan alat pengumpulan data yang dilakukan dengan cara mencermati, mengamati dan mencatat secara sistematis terhadap gejala-gejala yang diselidiki. Observasi juga merupakan suatu proses yang kompleks, suatu proses yang tersusun dari berbagai proses biologis dan psikhologis. Dua diantara yang terpenting adalah proses-proses pengamatan dan ingatan. Metode ini dilakukan oleh peneliti untuk melihat bagaimana kegiatan dan operasional BMT Darussalam Fakultas Agama Islam dengan cara pengamatan secara langsung ke lokasi. Objek penelitian dan pencatatan secara sistematis terhadap fenomena-fenomena yang sedang diteliti yang berhubungan dengan peranan BMT Darussalam yang berupaa adanya program pembiayaan untuk memenuhi kebutuhan mahasiswa FAI UIR meliputi : Pertama, Produk Seperti : Program Pembiayaan Akademik, Program Pembiayaan Sarana Akademik dan Program Pembiayaan Untuk Mahasiswa Berwirausaha. Kedua, Peranan BMT dalam memenuhi kebutuhan mahasiswa FAI UIR yang berupa program pembiayaan yang dibutuhkan oleh mahasiswa. 


\section{Wawancara}

Merupakan kegiatan tanya jawab secara lisan antara dua orang atau lebih secara langsung atau proses memperoleh keterangan untuk tujuan penelitian dengan cara tanya jawab sambil bertatap muka antara pewawancara dan informan. Wawancara dengan sumber yang terkait dengan pejabat atau unsur-unsur yang terlibat didalam BMT Darussalam Fakultas Agama Islam Universitas Islam Riau.

\section{Dokumentasi}

Dokumentasi adalah teknik pengumpulan data yang tidak langsung ditujukan pada subjek peneliti, namun melalui dokumen. Dokumentasi bisa berbentuk tulisan, gambar dan karyakarya monumental dari seseorang. Dokumentasi ini dimaksudkan untuk memperoleh bukti mengenai praktik pengajuan pembiayaan seperti persyaratan-persyaratan pengajuan pembiayaan bagi mahasiswa yang ingin melakukan pembiayaan.

Metode Analisa Data

Setelah data berhasil dikumpulkan, selanjutnya penulis menganalisa data tersebut dengan menggunakan metode deskriptif kualitatif, yaitu menganalisa data atas dasar - dasar persamaan jenis data, dan fenomena sosial yang tengah diteliti. Metode deskriptif digunakan setelah data yang diperlukan diperoleh, lalu data tersebut dikelompokkan dan diuraikan sesuai dengan jenisnya dan dianalisa dengan menggunakan analisis kualitatif, kemudian disajikan dalam bentuk tabel yang dilengkapi dengan penjelasan.

\section{HASIL DAN PEMBAHASAN} Analisis Peranan BMT

Tabel 2. Tabulasi Data Peranan BMT

\begin{tabular}{|c|c|c|c|}
\hline Variabel & Item Pernyataan & $\mathbf{Y a}$ & Tidak \\
\hline \multirow{6}{*}{ Peranan BMT } & $\begin{array}{llcc}\text { Transaksi } & \text { keuangan yang dijalankan oleh } & \text { BMT } \\
\text { Darussalam FAI UIR sesuai dengan Prinsip Syariah } & \end{array}$ & 83 & 5 \\
\hline & $\begin{array}{l}\text { Pembiayaan yang diberikan BMT Darussalam FAI UIR } \\
\text { dapat membantu mahasiswa yang terkendala dalam hal } \\
\text { dana pendidikan }\end{array}$ & 85 & 3 \\
\hline & $\begin{array}{l}\text { Melakukan pembinaan dan pendanaan bagi usaha kecil } \\
\text { mahasiswa dalam berwirausaha }\end{array}$ & 67 & 21 \\
\hline & $\begin{array}{l}\text { Adanya penjelasan yang diberikan oleh BMT Darussalam } \\
\text { FAI UIR kepada mahasiswa tentang pembiayaan }\end{array}$ & 84 & 4 \\
\hline & $\begin{array}{l}\text { Sistem Administrasi yang diterapkan BMT Darussalam } \\
\text { sudah baik }\end{array}$ & 60 & 28 \\
\hline & $\begin{array}{l}\text { Keberadaan BMT Darussalam FAI UIR memberikan } \\
\text { manfaat kepada mahasiswa }\end{array}$ & 84 & 4 \\
\hline & Rata-rata & 77.17 & 10.83 \\
\hline & Persentase & 87.69 & 12.31 \\
\hline
\end{tabular}

Sumber: Data Olahan (2019)

Berdasarkan hasil uji tanggapan responden dari data pada Tabel 2 diatas dapat dilihat bahwa tanggapan responden mengenai variabel Peranan BMT memperoleh respon sangat baik oleh mahasiswa yang mengajukan pembiayaan. Jawaban "Ya" paling dominan pada pernyataan pembiayaan yang diberikan BMT Darussalam FAI UIR dapat membantu mahasiswa yang terkendala dalam hal dana pendidikan sebanyak 85 orang. Sedangkan responden yang menjawab "Tidak" hanya 3 orang.

Persentase jumlah keseluruhan reponden yang memilih jawaban "Ya" 
sebesar $87.69 \%$ dibandingkan dengan responden yang memilih jawaban "Tidak" hanya sebesar $12.31 \%$. Artinya BMT Darussalam berperan dalam Memenuhi Kebutuhan Mahasiswa Fakultas Agama Islam Universitas Islam Riau.

\section{Analisis Kebutuhan Mahasiswa}

Keberadaan BMT (Baitul Mal wat Tamwil) Darussalam Fakultas Agama Islam Universitas Islam Riau selain sebagai sarana praktik pembelajaran mahasiswa di bidang keuangan syraiah juga dituntut untuk ikut menggerakan perekonomian ummat. Kemudian, melalui BMT Darussalam senantiasa menyediakan bantuan untuk mahasiswa-mahasiswa yang membutuhkan bantuan dana pendidikan. Berikut disajikan tabulasi jawaban responden tentang kebutuhan mahasiswa sebagai berikut :

Tabel 3. Tabulasi Data Kebutuhan Mahasiswa

\begin{tabular}{|c|c|c|c|}
\hline Variabel & Item Pernyataan & Ya & Tidak \\
\hline \multirow{4}{*}{$\begin{array}{l}\text { Kebutuhan } \\
\text { Mahasiswa }\end{array}$} & $\begin{array}{l}\text { Mahasiswa yang mengalami kendala seperti dana } \\
\text { pendidikan dapat mengajukan pembiayaan di BMT } \\
\text { Darussalam FAI UIR }\end{array}$ & 87 & 1 \\
\hline & $\begin{array}{l}\text { Produk-produk pembiayaan yang terdapat pada } \\
\text { BMT Darussalam FAI UIR sesuai dengan } \\
\text { kebutuhan mahasiswa }\end{array}$ & 86 & 2 \\
\hline & $\begin{array}{l}\text { Terdapat program pembiayaan akademik berupa } \\
\text { biaya SKS, SPP, KKN, Skripsi dan lainnya benar- } \\
\text { benar dapat membantu kebutuhan mahasiswa }\end{array}$ & 84 & 4 \\
\hline & $\begin{array}{l}\text { Terdapat program pembiayaan sarana akademik } \\
\text { berupa biaya pembelian laptop, komputer yang } \\
\text { diperuntukkan hanya untuk kebutuhan sarana } \\
\text { pendidikan mahasiswa }\end{array}$ & 65 & 23 \\
\hline
\end{tabular}

Terdapat program pembiayaan untuk mahasiswa yang ingin berwirausaha berupa pemberian modal usaha bagi mahasiswa yang kekurangan dana untuk

66 22

\begin{tabular}{rrr}
\hline Rata-rata & $\mathbf{7 7 . 6 0}$ & 10.40 \\
\hline Persentase & $\mathbf{8 8 . 1 8}$ & 11.82 \\
\hline
\end{tabular}

Sumber: Data Olahan (2019)

Berdasarkan hasil uji tanggapan responden dari data pada Tabel 3 diatas dapat dilihat bahwa tanggapan responden mengenai variabel Kebutuhan Mahasiswa memperoleh respon sangat baik oleh mahasiswa yang mengajukan pembiayaan. Jawaban "Ya" paling dominan terdapat pada pernyataan mahasiswa yang mengalami kendala seperti dana pendidikan dapat mengajukan pembiayaan di BMT
Darussalam FAI UIR sebesar 87 orang. Sedangkan responden yang menjawab "Tidak" hanya 1 orang.

Persentase jumlah keseluruhan reponden yang memilih jawaban "Ya" sebesar $88.18 \%$ dibandingkan dengan responden yang memilih jawaban "Tidak" hanya sebesar $11.82 \%$. Artinya segala kebutuhan mahasiswa baik berupa kebutuhan pembiayaan akademik, kebutuhan pembiayaan sarana akademik 
dan kebutuhan pembiayaan untuk berwirausaha dapat terpenuhi dengan

BMT Darussalam pada awalnya didirikan guna untuk melatih mahasiswa Fakultas Agama Islam menabung dengan menyisihkan uang serta membantu mahasiswa dalam kesulitan pembayaran SPP dan SKS dengan memberikan pembiayaan Kafalah bil Ujrah bagi mahasiswa/i Fakultas Agama Islam. BMT Darussalam juga sebagai sarana simpan - pinjam bagi mahasiswa/i karyawan dan dosen Fakultas Agama Islam Universitas Islam Riau.

BMT Darussalam dalam menjalankan programnya mempunyai bermacam-macam produk yang disediakan untuk mahasiswa, salah satunya adalah produk pembiayaan dalam bentuk program pembiayaan akademik, yakni pembiayaan kafalah bil ujroh. Kafalah adalah akad penjaminan yang diberikan oleh penanggung (kafil) kepada pihak ketiga untuk memenuhi kewajiban pihak kedua atau yang ditanggung (makfuul 'anhu, ashil) (Fatwa DSN, Nomor: 57/DSNMUI/V/2007). Penerapan pada BMT yang menggunakan akad kafalah bil ujrah dan atas jasa tersebut memperoleh fee (ujrah). Dalam hal pembiayaan ini BMT bertindak sebagai penaggung kepada pihak ketiga dan mahasiswa sebagai tertanggung dan atas transaksi tersebut BMT mendapatkan ujrah.

Ketika mahasiswa mengajukan pembiayaan kemudian pihak BMT Darussalam menganalisa persyaratan pengajuan pembiayaan dan jika telah disetujui, maka dilakukan penanda tanganan perjanjian pembiayaan dan pengikat jaminan, kemudian penarikan pembiayaan atau pencairan biaya (realisasi pembiayaan). Pencairan pembiayaan di BMT Darussalam mempunyai waktu yang lebih cepat, yaitu paling cepat 1 hari dan paling baik oleh BMT Darussalam Fakultas Agama Islam Universitas Islam Riau. lambat sekitar 3 hari. Dalam pemberian pembiayaan BMT Darussalam memiliki tahap-tahap yang sudah dirancang sedemikian rupa untuk mempermudah dalam proses pemberian pembiayaan bagi mahasiswa Fakultas Agama Islam Universitas Islam Riau.

Kemudian dalam akad awal antara pihak BMT Darussalam dan mahasiswa, BMT membebankan biaya administrasi dan ujrah (upah/imbalan) kepada mahasiswa yang digunakan untuk pengelolaan pembiayaan kafalah bil ujroh dan murabahah. Ujrah sesuai perhitungan bulan dari besarnya pinjaman. Akan tetapi jika mahasiswa meminjam pembiayaan dalam jangka waktu 1 bulan maka tidak dibebankan ujrah, dan jika mahasiswa mengajukan pembiayaan dalam waktu lebih dari 1 bulan maka anggota dibebankan ujrah.

Pada penelitian ini, responden yang mengajukan pembiayaan mengatakan bahwa mereka sangat terbantu dalam pembayaran uang kuliah berupa SPP, SKS dan lainnya. Hal ini dapat dilihat dari pernyataan responden pada Tabel 4.4 diatas bahwa tanggapan responden mengenai variabel Peranan BMT memperoleh respon sangat baik oleh mahasiswa yang mengajukan pembiayaan. Jawaban "Ya" paling dominan pada pernyataan pembiayaan yang diberikan BMT Darussalam FAI UIR dapat membantu mahasiswa yang terkendala dalam hal dana pendidikan sebanyak 85 orang. Sedangkan responden yang menjawab "Tidak" hanya 3 orang. Artinya keberadaan BMT Darussalam FAI UIR memberikan manfaat kepada mahasiswa.

Jika kita lihat dari segi kebutuhan mahasiswa tersebut, maka kebutuhan ini termasuk kedalam katagori kebutuhan hajiyat yang merupakan kebutuhan sekunder atau kebutuhan setelah 
kebutuhan dharuriyat. Apabila kebutuhan hajiyat tidak terpenuhi tidak akan mengancam keselamatan kehidupan umat manusia, namun manusia tersebut akan mengalami kesulitan dalam melakukan suatu kegiatan. Kebutuhan ini merupakan penguat dari kebutuhan dharuriyat. Dalam penelitian Sagara \& Pratama (2016) menemukan kebutuhan ini dimaksud untuk memudahkan kehidupan, menghilangkan kesulitan atau menjadikan pemeliharaan yang lebih baik terhadap lima unsur pokok kehidupan manusia. Dengan adanya program dari BMT Darussalam tersebut maka mahasiswa yang mengalami kesulitan dalam melakukan suatu kegiatan dapat terbantu dalam proses perkuliahan.

Sebelum adanya bantuan berupa pembiayaan dari BMT Darussalam, mahasiswa kurang bersemangat untuk kuliah karena bingung mencari dana untuk kekurangan pembayaran uang kuliah. Namun setelah adanya pembiayaan ini mahasiswa jadi semangat dan giat untuk kuliah. Dari beberapa penjelasan diatas dapat diketahui bahwa BMT Darussalam berperan dalam memenuhi kebutuhan mahasiswa Fakultas Agama Islam Universitas Islam Riau. Hasil tanggapan mahasiswa dalam penelitian ini sejalan dengan penelitian yang dilakukan oleh Makmun (2015) dan Jazuli (2016) dimana nasabah memilih BMT adalah atas dasar pemenuhan kebutuhan dan kemudahan pembiayaan.

\section{PENUTUP}

\section{Kesimpulan}

Berdasarkan uraian data yang dijelaskan, mka dapat diambil kesimpulan bahwa keberadaan BMT Darussalam berperan aktif dalam memenuhi kebutuhan mahasiswa Fakultas Agama Islam UIR untuk membantu mahasiswa yang membutuhakan dana pendidikan dalam bentuk program pembiayaan. Adapun peranan BMT Darussalam meliputi tiga hal yaitu pertama, adanya program pembiayaan akademik, memberikan dana talangan kepada mahasiswa yang terkendala dalam pembayaran biaya kuliah seperti biaya pendidikan (SPP, SKS dan KKN), keperluan skripsi, pembuatan VISA dan pembuatan KITAS. Kedua, program pembiayaan sarana akademik, memberikan bantuan pembiayaan sarana akademik seperti laptop, printer, handphone dan lain-lain. Ketiga, program untuk mahasiswa berwirausaha, memberikan bantuan pembiayaan kepada mahasiswa berupa dana untuk berwirausaha. Dari program tersebut BMT menjadi mediator antara mahasiswa yang membutuhkan dana dengan pihak Universitas. Selanjutnya dilihat dari persentase variabel peranan BMT, jumlah keseluruhan reponden yang memilih jawaban "Ya" sebesar $87.69 \%$ dibandingkan dengan responden yang memilih jawaban "Tidak" hanya sebesar $12.31 \%$. Kemudian, segala kebutuhan mahasiswa baik berupa kebutuhan pembiayaan akademik, kebutuhan pembiayaan sarana akademik dan kebutuhan pembiayaan untuk berwirausaha dapat terpenuhi dengan baik oleh BMT Darussalam Fakultas Agama Islam UIR. Hal ini terlihat dari variabel kebutuhan mahasiswa, persentase jumlah keseluruhan reponden yang memilih jawaban "Ya" sebesar 88.18\% dibandingkan dengan responden yang memilih jawaban "Tidak" hanya sebesar $11.82 \%$.

\section{Saran}

Berdasarkan penelitian ini maka dapat disarankan kepada BMT Darussalam harus senantiasa meningkatkan layanan-layanan yang dimiliki mengingat respon mahasiswa 
dalam penelitian ini atas kehadiran BMT Darussalam sangat membantu mereka dari segi pembiayaan kuliah.

\section{DAFTAR PUSTAKA}

Haryoso, L. (2017). Penerapan Prinsip Pembiayaan Syariah

(Murabahah) pada BMT Bina Usaha di Kabupaten Semarang. Law and Justice, 2(1), 79-89.

Ismanto, K. (2015). Pengelolaan Baitul Maal pada Baitul Maal Wa Tamwil (BMT) di Kota Pekalongan. JurnalPenelitian, 12 (1), 24-38.

Jazuli, S. (2016). Analisis Swot strategi pemasaran produk pembiayaan pada BMT El-Syifa Ciganjur (Bachelor's thesis, Fakultas Dakwah dan Ilmu Komunikasi).

Makmun, S., \& Ratnasari, R. T. (2015). Faktor Nasabah Memilih BMT Mandiri Sejahtera Gresik. Jurnal Ekonomi Syariah Teori dan Terapan, 2(8).

Pritandhari, M. (2015). Analisis FaktorFaktor yang Mempengaruhi Loyalitas Pelanggan dan Dampaknya terhadap Keunggulan Bersaing (Studi pada BMT Amanah Ummah Sukoharjo). Jurnal Pendidikan Ekonomi UM Metro, 3(1), 41-56.
Sagara, Y., \& Pratama, M. A. (2016). Penguatan Ekonomi Kerakyatan Melalui Baitul Mal Tanwil (BMT) Sebagai Balai Usaha Mandiri Rakyat Terpadu (BUMRT). Social Science Education Journal, 3(1) 